\title{
強化ガラスの表面応力測定
}

\author{
北 野 一 郎*・都甲 英 俊** \\ $(*$ 日本板硝子(株)舞鶴工場, **日本板硝子(株)商品技術部)
}

\section{Measurement of Residual Surface Stress on Tempered Glass Plate.}

\author{
By \\ Ichiro KITANO* and Hidetoshi TOGO** \\ $\left(\begin{array}{l}* \text { Nippon Sheet Glass Co., Ltd., Maizuru Plant, Maizuru, } \\ * * \text { Nippon Sheet Glass Co., Ltd., Products \& Engineering Department, Itami }\end{array}\right)$
}

\begin{abstract}
Following methods are usually adopted for measuring the residual surface compression present on tempered glass, (1) Observation of relative retardation of light passing through the cross-section of the plate parallel to its surface by photoelastic techniques. (2) Calculation of the stress by measuring the resultant curvature of the plane when a certain amount of thickness was etched-off by hydrofluoric acid from one side of the sample.

However, these methods are inadequate for the non-destructive measurement of surface stress on commercial glass plates of large dimensions.

The method described here is pertaing to the surface stress-induced birefringence of glass with the result that the angle of total reflection obtained by contacting an optical prism on the sample surface is different between two polarized components. Namely, the refractive indices of the compressed surface for the ordinary ray polarized in plane perpendicular to the surface is greater than that for the extraordinary ray polarized in plane parallel to the surface, thus the critical angle of total reflection of the ordinary ray is greater than that of the extraordinary ray. Since this difference is directly related to the magnitude of the surface stress and is detected in the field view of telescope as two regions of different brightness separated by a sharp boundary, it is possible to measure the surface stress in a rapid and non-destructive manner by calibrating the scale division of the eyepiece field. Calibration was done by giving a known degree of cancellation to the surface compression with the tension caused by bending the central portion of the sample supported freely at both ends.

The constructed instrument provided very sharp boundary lines in the field of eyepiece and made it possible to determine the surface compressive stress on tempered glass with the accuracy of $\pm 0.6 \mathrm{~kg} / \mathrm{mm}^{2}$.
\end{abstract}

[Received August 12, 1971]

\section{1. 緒 言}

強化ガラスの表面に残留する圧縮応力は試料が小さい 場合には断面歪を光弾性実験により複屈折を観察して求 めることができるし，また試料の一方の表面層を弗酸で 一定の厚みだけ除層し，このときに生ずる面の暁みを測 定することによって算出することもできる.しかし大板 強化ガラスにたいしてはこれらの方法の適用は困難であ り, かつ実際の製造現場においては非破壞で簡単に表面 残留応力が測定できることが望ましい。このためには全 反射応力測定法が有効であるら.

全反射応力測定法は古くは Orowan, Argon ${ }^{1)}$ らによ

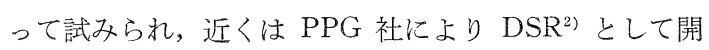
発されたと聞くが，文献に見られる全反射臨界線の写真
は，はなはだ不鮮明であり，また彼の地において該装置 を見学した人々の話を綜合してもその評洒注必ずしも高 くないようである・最近，わが国に扔いても全反射法に よる応力測定が 1,2 発表されているが3), ここに報告 する装置は, 岡村 ${ }^{4}$ の理論にもとづいて設計, 製作した ものである。

\section{1. 測 定 原 理}

ガラスは元来，等方等質透明体であるが，歪を受汀る と光学的異方性を示す.すなわち引張応力をうけるガラ スはその㐫力方向を光軸とする一軸性正結晶, たとえば 水晶と同じような光学的ふるまいを示し, 逆に圧縮応力 を受けるとその応力方向を結晶軸とする一軸性負結晶, 


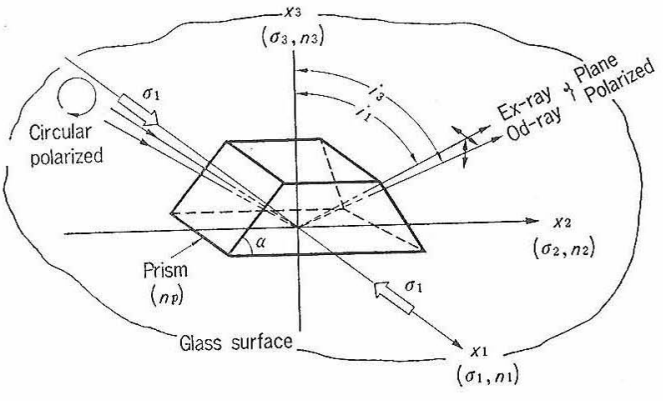

Fig. 1. Schematic presentation of difference of total reflecting angle for ordinary and extraordinary rays obtained by a refractive prism on. the glass surface under compressive stress.

たとえば方解石と同じ光学的暴方性を示す、いま，圧縮 応力が残留する強化ガラスの表面について考えてみると 負結晶としての光軸は表面に平行な平面内に存在する. したがって光軸と光の進行方向とを含を平面内において 進行方向湆角作動する異常光線と, 上述の平面に直 角に，かつ進行方向に垂直に振動する常光線とでは，光 軸以外の方南では進行速度を異にし，異常光線の速度は 常光線の速度より大，したがって異常光線にたいする屈 折率は常光線にたいする屈折率よりも小さい、いま， 図-1 に示すような圧縮応力が残留するガラス表面にお いて，その主莣力を $\sigma_{1} ， \sigma_{2}$ (いずれも表面に平行な平面 に存在し，たがいに直交する）および $\sigma_{3}$ (表面に直角) とし，それぞれの方向を光学的主軸 $x_{1}, x_{2}$ および $x_{3}$ であらわし，こ礼らの方向に振動する光の屈折率を $n_{1}$, $n_{2}$ および $n_{3}$ とすると，これら主応力と主屈折率の間 にはよく知られた次の関係式が成立する.

$$
\left.\begin{array}{l}
n_{1}-n_{0}=C_{1} \sigma_{1}+C_{2}\left(\sigma_{2}+\sigma_{3}\right) \\
n_{2}-n_{0}=C_{1} \sigma_{2}+C_{2}\left(\sigma_{3}+\sigma_{1}\right) \\
n_{3}-n_{0}=C_{1} \sigma_{3}+C_{2}\left(\sigma_{1}+\sigma_{2}\right)
\end{array}\right\}
$$

ここで, $n_{0}$ はガラスの無応力時の屈折率, $C_{1}$ は直接 光弾性定数， $C_{2}$ は獚光弾性定数であってこれらは使用 する波長によって定まるガラス固有なものである。光弾 性実験に用いられている光弾性定数は $C=C_{1}-C_{2}$ であ る.

いま, 測定に使用する光学プリズムの屈折率を $n_{p}$ (> $\left.n_{0}\right)$ ，プリズムの角度をいとし， ※は次の（2）式で求め られる無歪ガラスとプリズムとの全反射角 $i_{0}$ に等しい ように製作する。

$$
n_{0}=n_{p} \sin i_{0}
$$

このようなプリズムを強化ガラス表面に置き, 図-1に 示すようにレンズからの収㪘光束を角度 $\propto$ のプリズム面 にほぼ直角に入射せしめると各主軸方向に振動する偏光 にたいする全反射臨界角 $i_{s}(s=1.2,3)$ は，

$$
n_{s}=n_{p} \sin i_{s}(s=1,2,3)
$$

となるから各主軸にたいする屈折率の差は (2) 式および (3) 式より

$$
\begin{aligned}
n_{s}-n_{0} & =n_{p}\left(\sin i_{s}-\sin i_{0}\right) \\
& =2 n_{p} \cos \left(\frac{i_{s}+i_{0}}{2}\right) \sin \left(\frac{i_{s}-i_{0}}{2}\right)
\end{aligned}
$$

となるが， $i_{s}(s=1 ， 2 ， 3)$ と $i_{0}$ はそれぞれたがいに極 めて近い值であるから

$$
n_{s}-n_{0}=n_{p}\left(i_{s}-i_{0}\right) \cos i_{0} \ldots
$$

図-1 に掠いて光束の方向を主応力の 1 つ,たとえば $x_{1}$ 力向に直角とすれば光束に平行な $x_{2}$ 方向には光の 分解はないから (4) 式で $s=1,3$ のみを考光ると, 次 式が得られる。

$$
i_{1}-i_{3}=\frac{n_{1}-n_{3}}{n_{p} \cos i_{0}}
$$

光はプリズム加ら空気中に出ると僻は $n_{p} / 1$ 倍にな るから

$$
i_{1}-i_{3}=\frac{n_{1}-n_{3}}{\cos i_{0}}
$$

一方，(1) 式より

$$
n_{1}-n_{3}=C\left(\sigma_{1}-\sigma_{3}\right)
$$

実際には $x_{3}$ 方向の応力 $\sigma_{3} \approx 0$ とみなしてよいから (5) 式拉よび (6) 式から

$$
\sigma_{1}=\frac{\cos i_{0}}{C}\left(i_{1}-i_{3}\right)
$$

$i_{0}$ および $C$ は一定であるからガラス表面上の主応力 は異常光線および常光線に対する全反射臨界角の差 $\left(i_{1}-i_{3}\right)$ k比例することがわかる. $\left(i_{1}-i_{3}\right)$ はオートコ リメータによって直接読みとることが可能であるから （7）式によって残留応力值を知ることができる.

\section{3. 測 定 装 置}

図-2 は製作した表面応力測定器の外観を示す写真, 図-3 はその概略図である.図-3 において(1)はナトリウ ムランプ，(2)〜(5)は光学レンズ系で，これらは筐体(6に 収容される。(7)は円偏光板，(8)はコリメータレンズで反 射鏡(9によりほぼ全反射角でプリズム(10)の端面に直角 に，ガラス表面上のスポットに投射される。(11)よび(12) はプリズムの微動調整装置である．反射光は反射鏡(13に

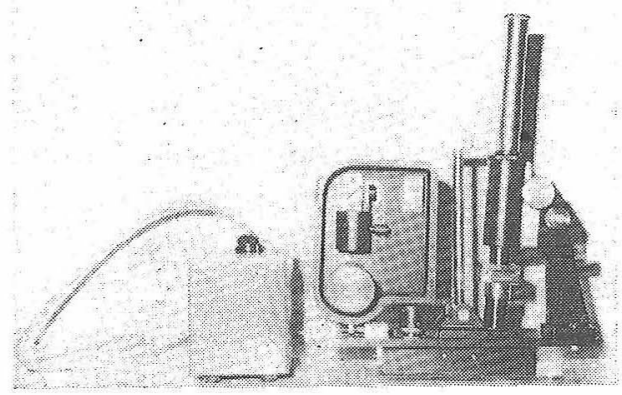

Fig. 2. Side view of the instrument. 


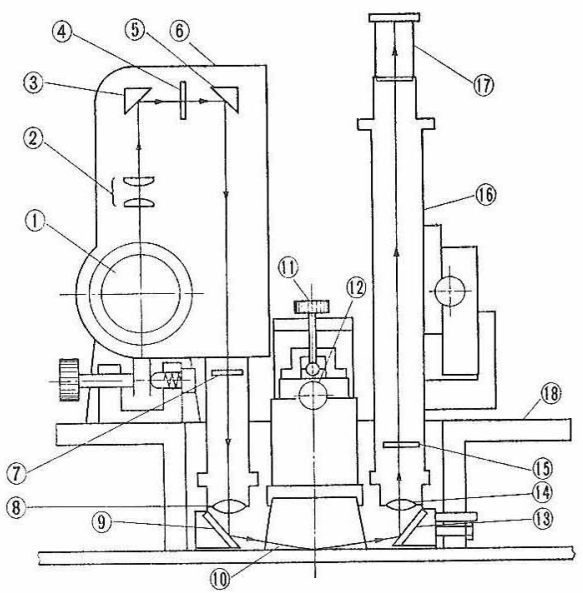

Fig. 3. Cross sectional view of the instrument.

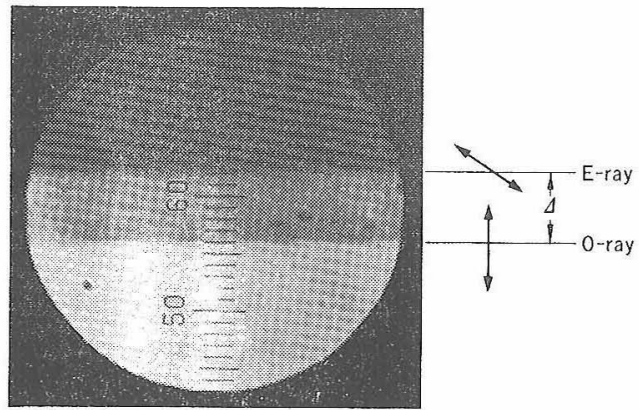

Fig. 4. An example of eyepiece field in which two boundary-lines appear corresponding to the different critical angle of total reflection for ordinary and extraordinary rays respectively.

より対物レンズ(14)よび 偏光板 (15)を通って鏡筒(16)に

り，接眼鏡117の視野に 図-4 の写真の例に見られるよう

に, 常光線と異常光線の屈折率の差違によるそれぞれの 全反射臨界線を明膫に現わし，雨境界線の差 $\Delta$ を視野の 目盛で正確に読取ることができる。偏光板(15)は 2 枚の偏 光板を中央で直交， 2 分割しているので，これを左右に 動かせば視野中のいずれか一方の境界線を消すことがで きる.プリズムと試料ガラス表面の閒には，光学的接触 とするために両者の中閒に屈折率值をもつクローブ油を 插大した．プリズムの材質には光学ガラス LLF $6\left(n_{p}\right.$ $=1.5371$ ) 等選び，その角度 $\alpha$ は（2）式より $\alpha \approx i_{0}=$ $81^{\circ} 40^{\prime}$ に製作した。

\section{4. 实験結果と考察}

視野の目盛に対する応力值を知るため，短冊状強化ガ ラスの両端を自由支持し，中央にプリズムを置き，下方 加ら試料中央部に一定量の変形を与えることによって生 ずる表面の引張応力により，強化ガラスの表面残留圧縮 応力定逐次消去せしめ，対応する視野の目盛を読んだ。
曲げによって生ずる引張応力は次式から求めた。

$$
\sigma_{t}=\frac{6 E h}{l^{2}} \delta
$$

ただし， $\sigma_{t}$ : 表面引張応力 $\mathrm{kg} / \mathrm{mm}^{2}, E$ : 強化ガラス のヤング率 $7500 \mathrm{~kg} / \mathrm{mm}^{2}, h:$ 厚み $\mathrm{mm}$, $l:$ スパンの長さ $\mathrm{mm}, \delta:$ 曲げ量 $\mathrm{mm}$

得られた結果を図-5 に示す。この応力值だけ減少し て表面に残存する圧縮応力と視野目盛との関倸が必要な 較正曲線であってこれを 図-6に示す。一方, 強化度の 異なる試料 4 種につき図-7 図-10 に見られるような常 光線と異常光線との間の微小な全反射臨界角の差 $\left(i_{1}-\right.$ $i_{3}$ ) を直接オートコリメータで実測し，視野の目盛 $\Delta$ と $\left(i_{1}-i_{3}\right)$ との関係を求めたところ，図-6のような結果と

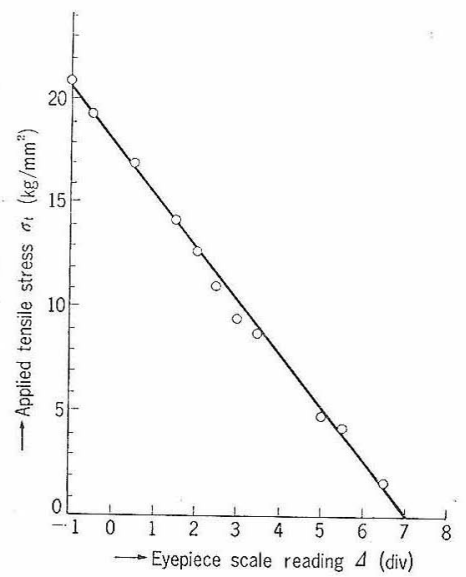

Fig. 5. Cancellation of residual compressive stress by applying tensile stress caused by bending the sample.

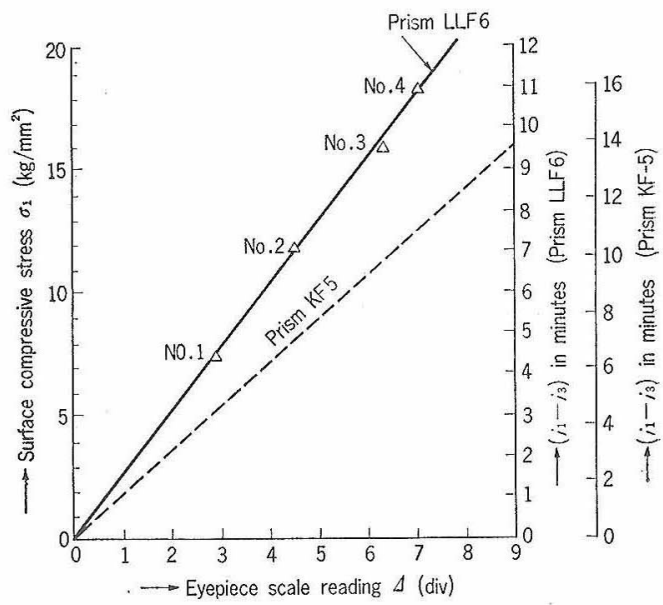

Fig. 6. Calibration curve of eyepiece scale reading $\Delta$ of the instrument. The curve is checked by measuring directly the difference of total reflecting angle $\left(i_{1}-i_{3}\right)$ by autocollimator for samples No. $1 \sim 4$ shown in photographs from Fig. 7 to 10 . 


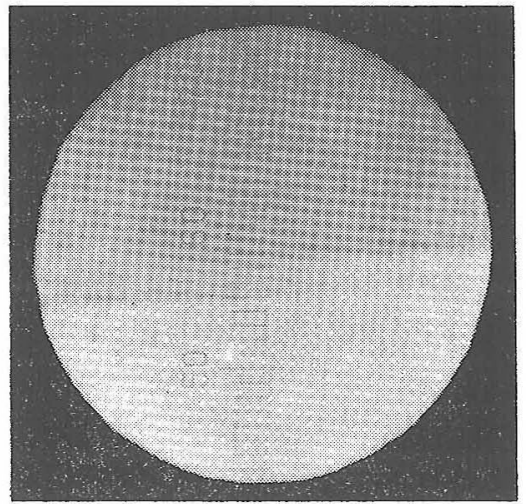

Fig. 7. Sample No. 1.

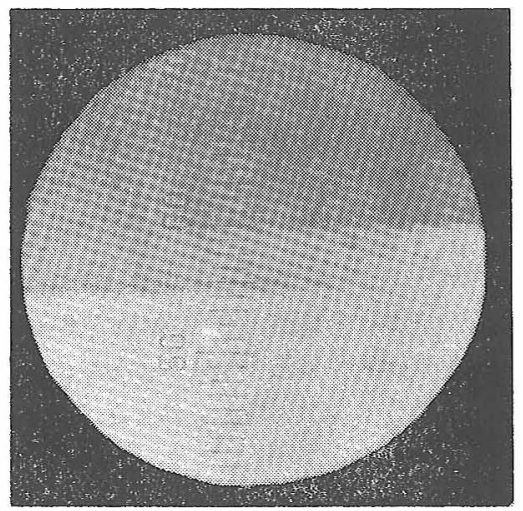

Fig. 8. Sample No. 2.

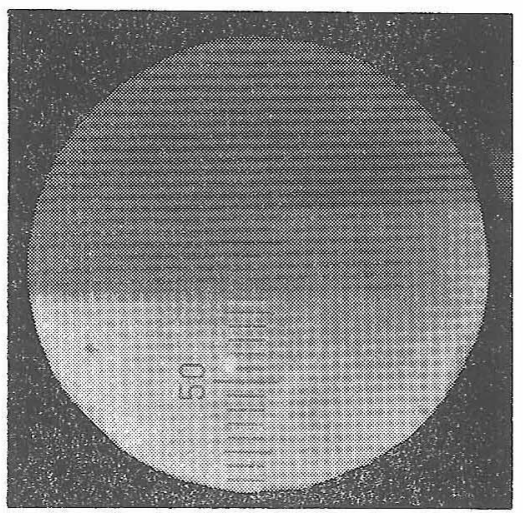

Fig. 9. Sample No. 3.

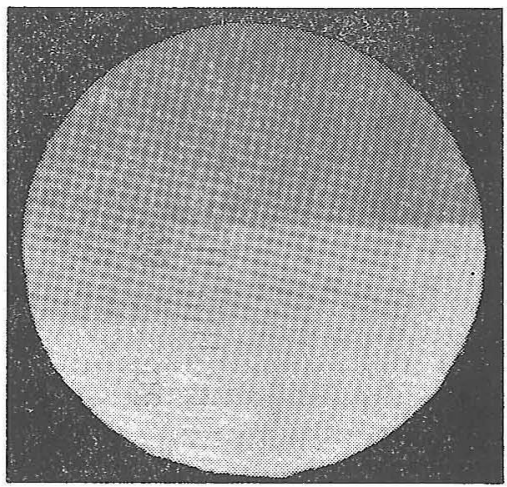

Fig. 10. Sample No. 4.
なった。図-7〜図-10 の写真で常光線および異常光線の 境界が，いずれか一方で消えているのは，前述の直交偏 光板を視野中央において撮影したからである。

さて，(7) 式に执いて $C=2.5 \times 10^{-5} \mathrm{~mm}^{2} / \mathrm{kg}, \sin i_{0}$ $=n_{0} / n_{p}=1.5157 / 1.5317=0.989$ を用いると,

$$
\sigma_{1}=5.76 \times 10^{3}\left(i_{1}-i_{3}\right)
$$

ここで $\sigma_{1}: \mathrm{kg} / \mathrm{mm}^{2}, i_{1}-i_{3}: \mathrm{rad}$.

したがって，全反射臨界角差 $\left(i_{1}-i_{3}\right)$ と応力值は比 例関係にあり 図-6 の左右の縦軸で対充せしめることが できる、この网の直線は前述のように曲げ実験によって 得られたものであって，この直線上に，強化度走異にす る種々の試料の応力值がほぼのることから，図-6 莡本 装䁂の較正曲線として使用できること在確認し得たわけ である。

視野に現われる境界線の目盛上での読取精度は視野の 写真（図-4 怙よ゙図-7〜10）加ら容易にわかるように $\Delta=0.5$ ，すなわち虑力值にして 図-6 から $1.2 \mathrm{~kg} / \mathrm{mm}^{2}$ は充分判別できるから応力测定精度としては，お拉よそ 上0.6 kg/mm² であるといえる.

実際に大板強化ガラスの表面芯力測定に当っては，被 測定点を通る主応力方向はほぼ放射状に対称であるた め，(1) 式において $\sigma_{1} \approx \sigma_{2}$ となり，したがってプリズ 厶を試料表面上でどの方向に向けても視野の目盛差の読 み みほとんど同じであった，

本器ではプリズムとして届折率 $n_{p}=1.5317$ の光学ガ ラス LLF-6 を使用したが，一般に $n_{p}$ を試料の屆折率 に近ゔけと測定精度が上る。たとえば $n_{p}=1.5231$ の 光学ガラス $\mathrm{KF}-5$ で, (2) 式の角度 $\alpha=84^{\circ} 20^{\prime}$ のプリ ズム学使用すると(9)式に相当する式は，

$$
\sigma_{1}=3.96 \times 10^{3}\left(i_{1}-i_{3}\right)
$$

（ただし $\sigma_{1}: \mathrm{kg} / \mathrm{mm}^{2} ，\left(i_{1}-i_{3}\right): \operatorname{rad}$ ) となり，かつ 視野の読み $\Delta$ は $\left(i_{1}-i_{3}\right)$ に比例するので，応力対視野 目盛差の関係は 図-6の点線に示すようになり，4の読 取精度 0.5 にたいする忘力值は $0.8 \mathrm{~kg} / \mathrm{mm}^{2}$. すなわち 応力測定精度として $\pm 0.4 \mathrm{~kg} / \mathrm{mm}^{2}$ と良くなる。しか し余り $n_{p}$ を $n_{0}$ に近うけるとかえって視野の臨界線に ボケを生ずるかから，実用的には普通の板ガラス組成の 強化ガラス用としては本器に使用したプリズムで充分で あると考える。

\section{5. 総括}

圧縮忘力が残留する強化板ガラス表面に，これより屈 折率の僅かに大きいプリズムを置き，被測定点に収㪘す る円偏光光束を全反射臨界角にほぼ等しい角磨で入射せ しめると，試料表面上で入射面に垂直な主応力少に振 動する異常光線の屆折率は，入射面内で試料表面に垂直 な方向に振動する常光線の屈折率より小さいために，反 射臨界角は常光線のほうが大で，したがって望遠鏡の視 
野に現われる明暗の全反射境界線の間には両者間でずれ を生ずる.この差違は表面に存在する応力に比例するの で，視野の目盛を既知応力であらかじめ較正しておけげ 表面応力を非破壞で知ることができる，この原理に基づ き現場で使い易くコンパクトな光学装置を製作したが, 視野に見られる常, 異常両光線にたいする明暗の全反射 境界線の差は極內て明膫であり, 強化ガラスの表面応力 を $\pm 0.6 \mathrm{~kg} / \mathrm{cm}^{2}$ の測定精度で測定することができた。

本研究は著者らが研究所在任中に行なったものであり, 御指 導, 討論をいただいた東大工学部岡村弘之助教授, 当社音在研
究所長および中谷商品技術部長の諸氏，また実際に本器を使用 し有益な助言をいただいた鈴木主任技師らに厚く感謝の意を表 す次第である。

\section{文献}

1) A.S. Argon, "MIT Masters Thesis in Mechanical Engineering” (1953).

2) R.W. Ansevin, ISA Transactions 4 [4] 339-43 (1965).

3) 原 守久, 第 9 回ガラス部会討論会講演要旨集, p. 3944 (1971).

4）岡村弘之, 機械学会論文集 30 [215] 745-55 (1964).

$[8 / 12 / 1971$ 受付 $]$

\section{正 誤 表}

光学ガラス表面の酸によるくもり＼cjkstart芝山彦右・河本洋二・土橋正二 案業協会誌 80 [2] 43-52 (1972).

\begin{tabular}{cccc}
\hline \multicolumn{2}{c}{ ページ } & 誤 & 正 \\
\hline 44 & Table 1 & $\mathrm{Mn}_{2} \mathrm{O}_{3}$ & $\mathrm{TiO}_{2}$ \\
\hline
\end{tabular}

